\title{
ANALISIS EKONOMI USAHA PENGOLAHAN LIMBAH JERAMI PADI MENJADI PAKAN AMONIASI DI DESA BATU KUTA LOMBOK BARAT
}

\section{ECONOMIC ANALYSIS OF BUSINESS PROCESSING RICE STRAW WASTE INTO AMMONIATION FEED IN BATU KUTA VILLAGE, WEST LOMBOK}

\author{
Abyadul Fitriyah ${ }^{1}$, Ria Harmayani ${ }^{1}$, Aisah Jamili ${ }^{1}$, Yuni Mariani ${ }^{1}$, Ni Made Andry \\ Kartika $^{1}$, dan Isyaturriyadhah ${ }^{2}$ \\ ${ }^{1}$ Universitas Nahdlatul Wathan Mataram, \\ Jl. Kaktus 1-3 Kota Mataram 83125 NTB \\ ${ }^{2}$ Program Studi Agribisnis, Fakultas Pertanian, Universitas Muara Bungo, Jl. Pendidikan, RT. \\ 10 RW. 02 No. 10 Kelurahan Sungai Binjai. Kecamatan Bathin III. Kabupaten Bungo, Jambi \\ 37228, Indonesia \\ abyadulfitriyah@gmail.com, isyaturriyadhah_amin@yahoo.com
}

\begin{abstract}
ABSTRAK
Tujuan dari peneilitian ini adalah untuk menganalisis besarnya biaya dalam mengelola usaha pakan Amoniasi pada kelompok Tani Ternak (KTT) Wiresinge di desa Batu Kuta Lombok Barat, dan untuk mengetahui besarnya pendapatan serta $\mathrm{R} / \mathrm{C}$ rasio dari usaha tersebut. Penelitian ini menggunakan metode deskriptif kuantitatif dengan teknik survey. Adapun jumlah sampel yang digunakan dalam penelitian ini sebanyak 40 orang responden yang berasal dari KTT Wiresinge dan dipilih secara simple random sampling. Sedangkan pemilihan lokasi penelitian dilakukan secara purposive. Besarnya biaya dalam mengelola usaha pakan Amoniasi pada KTT Wiresinge di desa Batu Kuta Lombok Barat dapat diketahui melalui analisis biaya produksi. Sedangkan untuk mengetahui besarnya pendapatan dari usaha pakan Amoniasi tersebut telah dilakukan analisis pendapatan dan analisis Return Cost Ratio (R/C Ratio) untuk mengetahui untung ruginya usaha. Hasil penelitian menunjukkan bahwa biaya yang dikeluarkan dalam mengelola usaha pakan Amoniasi pada KTT Wiresinge di desa Batu Kuta Lombok Barat sebesar Rp. 1.383.000,- per satu kali masa produksi (dua minggu). Sedangkan pendapatan dalam satu kali masa produksi (dua minggu) yang di peroleh KTT Wiresinge dari usaha pakan Amoniasi adalah rata-rata Rp. 317.000,-. Dapat disimpulkan bahwa secara ekonomis pakan Amoniasi ini menguntungkan sebagai usaha dan menguntungkan jika dikembangkan di desa Batu Kuta Lombok Barat, karna nilai R/C Ratio yang diperoleh sebesar 1.23, jika $\mathrm{R} / \mathrm{C}>1$ artinya usaha ini menguntungkan.

Kata Kunci: Analisis ekonomi, Jerami padi, Pakan Amoniasi
\end{abstract}

\section{ABSTRACT}

This study aims to determine the running cost of the ammoniation feed business in Wirasinge's rancher's group (KTT Wiresinge) at Batu Kuta Lombok Barat, and to determine the income, also $R / C$ ratio of the business. This study used descriptive quantitative analysis method by survey technique. The total samples are forty (40) respondents were taken in simple random sampling. The selection of the research location was conducted by purposive. The running cost of the ammoniation feed business of KTT Wiresinge at Batu Kuta Lombok Barat is carried out by analysis of production costs. To find out the business income of the ammoniation feed business was analyzed using an income analysis, and to find out the gross income of the ammoniation feed business was analyzed using Return Cost Ratio (R/C Ratio)'s 
formula. The results showed that the running cost of the ammoniation feed business is IDR. 1.383.000,- per production time ( two weeks). While the average net income of the ammoniation feed business per production time (two weeks) is IDR 317.000,-. It can be concluded that economically the ammoniation feed at Batu Kuta Lombok Barat is feasible to be cultivated and developed because the $R / C$ Ratio value was obtained 1.23 , if the value of $R / C>1$, that is means the business is profitable.

Keywords: Economic analysis, Rice straw, Ammoniation feed

\section{PENDAHULUAN}

Potensi jerami padi, khususnya di Indonesia (pulau Lombok) sangat besar. Pada musim hujan para peternak tradisional dapat memberi sapinya dengan hijauan segar yang berlimpah, namun pada musim kemarau (paceklik) sebagian besar petani peternak memberi pakan ternaknya dengan jerami tanpa diolah. Meskipun jerami ini dapat di makan oleh sapi, namun sebagian tidak tercerna dan tidak akan menjadikan gemuk bagi ternaknya. Hal ini dikarenakan jerami padi mempunyai serat kasar yang tinggi $(35-40 \%)$ dan protein yang rendah $(3-4 \%)$. Dengan produksi padi sebanyak 161,60 ton per tahun di desa Batu Kuta Lombok Barat (Statistik, 2020), maka sangatlah sayang kalau potensi jeraminya diabaikan.

Jerami padi ini dapat diolah, diantaranya menjadi pakan Amoniasi dengan tujuan untuk meningkatkan kandungan protein bahan pakan tersebut. Pengolahan Jerami padi menjadi pakan Amoniasi ini mudah untuk dilakukan dan siapa saja dapat melakukan asal mengerti dengan jelas prinsip dan metode mana yang akan dilakukan. Sehingga teknologi pengolahan pakan ini bisa diterapkan di desa Batu Kuta, mengingat potensi desa Batu Kuta sebagai salah satu daerah pertanian dan perternakan yang cukup potensial di Kabupaten Lombok Barat.

Desa Batukuta Kecamatan Narmada Kabupaten Lombok Barat memiliki potensi cukup besar dibidang peternakan, pertanian, perikanan dan aneka usaha yang lain. Potensi peternakan sapi cukup besar dimiliki masyarakat Desa Batu kuta. Dengan jumlah peternak sapi dan kambing
75 orang dan jumlah sapi mencapai 339 ekor (Statistik, 2020). Adapun permasalahan yang dihadapi antara lain, sampai saat ini ternak sapi tersebut tidak mendapatkan pakan yang sesuai dengan kebutuhannya sehingga menyebabkan pertumbuhannya lambat, produksinya menurun, kualitas dagingnya rendah, bahkan dapat menyebabkan kematian karena kekurangan pakan atau rendahnya kandungan nutrisi dari pakan yang dikonsumsinya.

Disisi lain, bahan pakan alami dengan kandungan nutrisi yang tinggi seperti Jerami padi dengan kandungan protein 3,9\% untuk Jerami Padi Gogo dan 8,9\% untuk Jerami Padi IR (sapibagus, 2017), melimpah di desa Batu Kuta, tetapi memerlukan ilmu dan pengetahuan untuk mengolahnya, sedangkan masyarakat setempat belum tau cara mengolahnya, mereka hanya memberikan pakan basal jerami padi tanpa diolah dengan kandungan serat kasar yang tinggi (35 $40 \%)$ dan protein yang rendah $(3-4 \%)$ (Zhang et al., 2018). Hal inilah yang menyebabkan kondisi ternaknya memiliki kualitas yang rendah, seperti kurus, produksi rendah dan kualitas daging dibawah standar pasar.

Pengolahan limbah pertanian jerami padi menjadi pakan Amoniasi merupakan usaha yang dapat dilakukan secara sampingan. Walaupun hanya sebagai usaha sampingan jerami padi ini memiliki prospek yang sangat bagus, karena pakan Amoniasi mempunyai nilai jual dan ekonomi yang cukup tinggi. Saat ini limbah pertanian tersebut, hanya ditumpuk dan dibiarkan begitu saja sampai kering di pinggir sawah/ladang dan hanya sebagian 
yang digunakan sebagai pakan ternak. Pengolahan Jerami padi menjadi pupuk Amoniasi belum atau tidak dilakukan dengan memanfaatkan teknologi secara profesional. Menurut (Fikriman, 2017) bahwa dengan dibangunnya sektor pertanian yang baik maka hal ini juga akan berdampak baik bagi daerah pedesaan karena sektor pertanian merupakan sektor yang sangat berpengaruh bagi daerah pedesaan dalam hal untuk mendapatkan pendapatan riil pedesaan.

Berdasarkan uraian tersebut, maka dilakukan penelitian ini dengan memanfaatkan limbah pertanian yaitu Jerami padi untuk diolah menjadi pakan Amoniasi. Pengolahan Jerami padi menjadi pakan Amoniasi merupakan usaha sampingan di desa Batu Kuta Lombok Barat. Tujuan dari penelitian ini untuk menganalisis besarnya biaya dalam mengelola usaha pakan Amoniasi pada kelompok Tani Ternak (KTT) Wiresinge di desa Batu Kuta Lombok Barat, dan untuk mengetahui besarnya pendapatan serta mengetahui apakah usaha yang dilakukan KTT Wiresinge untung atau rugi.

\section{METODOLOGI}

Lokasi penelitian dipilih secara purposive sampling dengan pertimbangan bahwa KTT Wiresinge Desa Batu Kuta Lombok Barat memiliki potensi cukup besar dibidang peternakan dan pertanian dan belum memanfaatkan limbah pertanian secara maksimal sebagai usaha untuk meningkatkan pendapatannya secara ekonomi. Penelitian ini dilaksanakan pada bulan April 2021.

Penelitian ini menggunakan metode deskriptif kuantitatif, yaitu suatu metode untuk menggambarkan, menjelaskan, atau meringkas berbagai kondisi, situasi, fenomena, atau berbagai variable penelitian menurut kejadian sebagaimana adanya yang dapat dipotret, diwawancara, diobservasi, serta yang dapat diungkapkan melalui bahan-bahan dokumenter (savinotes, 2017); (Husaini Usman \& Purnomo Setiady Akbar, 2006).
Selanjutnya teknik penelitian dilaksanakan dengan menggunakan teknik survey yang memiliki ciri khas bahwa data dikumpulkan dari responden dengan menggunakan kuesioner (Fitriyah, 2020); (Nazir \& Sikmumbang, 2009). Penelitan ini mengambil data dengan melakukan wawancara dan observasi langsung kepada responden dengan menggunakan kuesioner yang telah dipersiapkan sebelumnya. Adapun jumlah sampel yang digunakan dalam penelitian ini sebanyak 40 orang responden yang berasal dari KTT Wiresinge dan dipilih secara simple random sampling.

Data dalam penelitian ini berasal dari data primer yang diperoleh dari responden KTT Wiresinge yang memiliki usaha pakan Amoniasi. Data ini diperoleh melalui wawancara langsung yang berpedoman pada daftar pertanyaan yang telah disediakan sebelumnya. Data lainnya diperoleh dari instansi-instansi yang terkait dengan penelitian ini, seperti kantor kecamatan dan kantor BPS Kabupaten Lombok Barat.

\section{Metode Analisis Data}

1. Untuk mengetahui total biaya yang dikeluarkan dalam suatu usaha maka digunakan rumus sebagai berikut :

$$
\mathbf{T C}=\mathbf{T F C}+\mathbf{T V C}
$$

Keterangan :

$$
\begin{aligned}
& \text { TC = Total Cost } / \text { Total Biaya } \\
& \text { (Rp) = Total Fixed Cost / Total } \\
& \text { TFC }=\text { Total Variable Cost / } \\
& \text { Biaya Tetap (Rp) } \\
& \text { TVC = } \\
& \text { Total Biaya Variabel (Rp) } \\
& \text { (Suratiyah, 2015). }
\end{aligned}
$$

2. Untuk mengetahui besarnya pendapatan dalam penelitian ini di hitung dengan rumus sebagai berikut:

$$
\mathbf{Y}=\mathbf{T R}-\mathbf{T C}
$$

Keterangan :

$$
\begin{aligned}
& \mathrm{Y}=\text { Pendapatan } \\
& \mathrm{TR}=\text { Total Revenue / } \\
& \text { Total Penerimaan }
\end{aligned}
$$




$$
\begin{aligned}
& \mathrm{TC}=\text { Total Cost } / \text { Total } \\
& \text { Biaya }
\end{aligned}
$$

$\mathbf{T R}=\mathbf{Q} \times \mathbf{P Q}$

Keterangan :

$$
\mathrm{Q}=\text { Quantity / Total }
$$

Produk yang terjual

$$
\text { PQ = Price Quantity / }
$$

\section{Harga Produk (Rp)}

\section{Analisis R/C Rasio}

Untuk mengetahui berapa besar penerimaan yang diterima untuk setiap rupiah yang dikeluarkan dalam kegiatan produksi maka digunakan "Return Cost Ratio" dengan rumus:

Keterangan :

$$
\mathrm{R} / \mathrm{C}=\frac{\text { Penerimaan }}{\text { Total Biaya }}
$$

Kriteria kelayakan usaha pakan amoniasi dikelompokkan menjadi tiga yaitu :

a) Apabila R/C $>1$, berarti untuk pengeluaran biaya produksi sebesar Rp. 1 akan mendapatkan penerimaan lebih dari Rp. 1 (untung).

b) Apabila R/C <1, berarti untuk pengeluaran biaya produksi sebesar Rp. 1 akan mendapatkan penerimaan kurang dari Rp. 1 (rugi).

c) Apabila $\mathrm{R} / \mathrm{C}=1$, berarti untuk pengeluaran biaya produksi sebesar Rp. 1 akan mendapatkan penerimaan sama dengan Rp. 1 (impas) (Sulastri, 2016).

\section{HASIL DAN PEMBAHASAN}

Mengacu pada metodologi penelitian, hasil penelitian diuraikan sebagai berikut:

\section{Analisis Ekonomi Usaha Pakan Amoniasi}

\section{Biaya Produksi}

Biaya produksi merupakan keseluruhan biaya yang di keluarkan oleh KTT Wiresinge, yang dikelompokkan menjadi biaya tetap (Fixed Cost) dan biaya tidak tetap (Variable Cost)

\section{Biaya Tetap (Fixed Cost)}

Dalam usaha pakan Amoniasi, yang termasuk ke dalam biaya tetap adalah biaya sewa gudang dan penyusutan peralatan. Berdasarkan hasil penelitian ini bahwa, rata-rata biaya tetap yang di keluarkan oleh masing-masing responden (KTT Wiresinge) perskala produksi (2 minggu) adalah Rp.209.000,-, dengan

\begin{tabular}{|c|c|c|c|}
\hline $\begin{array}{l}\mathbf{N} \\
\mathbf{o}\end{array}$ & $\begin{array}{c}\text { Kompone } \\
\text { n Biaya } \\
\text { Tetap }\end{array}$ & $\begin{array}{l}\text { Biaya } \\
\text { Rata- } \\
\text { rata } \\
\text { (Rp/skala } \\
\text { produksi } \\
\text { ) }\end{array}$ & $\begin{array}{l}\text { Presentas } \\
\text { e }(\%)\end{array}$ \\
\hline 1 & $\begin{array}{l}\text { Sewa } \\
\text { Gudang }\end{array}$ & 167.000,- & $79.91 \%$ \\
\hline \multirow[t]{2}{*}{2} & $\begin{array}{l}\text { Penyusutan } \\
\text { Peralatan }\end{array}$ & $42.000,-$ & $20.09 \%$ \\
\hline & Jumlah & 209.000,- & 100.0 \\
\hline
\end{tabular}
rincian seperti tertera pada Tabel 1 .

Tabel 1. Biaya Tetap yang dikeluarkan oleh responden (KTT Wiresinge)

Sumber : Data Primer diolah, 2021

Berdasarkan tabel 1 di atas, bahwa biaya tetap yang di keluarkan oleh KTT Wiresinge meliputi biaya sewa gudang sebesar $79.91 \%$ dan biaya penyusutan peralatan mencapai $20.09 \%$. Adapun biaya penyusutan peralatan yang dimaksud diantaranya, timbangan, alat pengaduk dan ember.

\section{Biaya Tidak Tetap (Variable Cost)}

Biaya tidak tetap (Variable Cost) merupakan biaya yang di keluarkan oleh responden (KTT Wiresinge), meliputi biaya jerami padi, molases, urea, tenaga kerja dan plastic Amoniasi. Rincian ratarata jumlah biaya tidak tetap dapat di lihat pada Tabel 2. 
Tabel 4. Penerimaan responden (KTT Wiresinge) dari usaha pakan Amoniasi

\begin{tabular}{|c|c|c|c|c|}
\hline $\mathbf{N}$ & $\begin{array}{c}\text { Kompo } \\
\text { nen }\end{array}$ & $\begin{array}{l}\text { Harg } \\
\text { a } \\
\text { Jual } \\
\text { (Rp/k } \\
\text { g) }\end{array}$ & $\begin{array}{l}\text { Nilai } \\
\text { Rata- } \\
\text { rata } \\
\text { Terjual } \\
\text { (kg/ska } \\
\text { la } \\
\text { produk } \\
\text { si) } \\
\end{array}$ & $\begin{array}{l}\text { Total } \\
\text { (Rp) }\end{array}$ \\
\hline 1 & $\begin{array}{l}\text { Nilai } \\
\text { jual } \\
\text { pakan } \\
\text { Amonias } \\
\text { i }\end{array}$ & $\begin{array}{l}20.00 \\
0,-\end{array}$ & 85 & $\begin{array}{l}1.700 .00 \\
0,-\end{array}$ \\
\hline
\end{tabular}

Sumber : Data Primer diolah, 2021

Dari Tabel 4 terlihat bahwa penerimaan responden (KTT Wiresinge) dari usaha pakan Amoniasi perskala produksi yaitu sebesar Rp. 1.700.000,-. Adapun besarnya pendapatan responden (KTT Wiresinge) dari usaha pakan Amoniasi, seperti tertera pada Tabel 5.

Tabel 5. Pendapatan responden (KTT Wiresinge) dari usaha pakan Amoniasi

\begin{tabular}{clc}
\hline No & Komponen & $\begin{array}{l}\text { Nilai (Rp/skala } \\
\text { produksi) }\end{array}$ \\
\hline 1 & Penerimaan & $1.700 .000,-$ \\
2 & Biaya Produksi & $1.383 .000,-$ \\
& Jumlah & $317.000,-$ \\
\hline
\end{tabular}

Sumber : Data Primer diolah, 2021

Dari Tabel 5 terlihat bahwa pendapatan rata-rata KTT Wiresinge dalam usaha pakan Amoniasi yaitu 317.000 ,- per skala produksi. Usaha ini juga bisa dikatakan untung karena kondisi real di lapangan responden tidak membeli jerami padi karena jerami padi tersedia melimpah bahkan menjadi limbah, namun karena kegiatan ini merupakan analisis ekonomi maka biaya jerami padi tetap dihitung sebagai biaya variable.

Dengan memperhatikan pendapatan yang diperoleh KTT Wiresinge, maka pendapatan dari usaha pakan Amoniasi untuk 1x produksi di desa Batu Kuta Lombok Barat ini dikatakan tinggi. Untuk itu, harusnya usaha pakan Amoniasi ini dijadikan sebagai usaha pokok bukan sebagai usaha sampingan yang selama ini dijalankan.

\section{R/C Rasio}

Nilai penerimaan atas biaya $(\mathrm{R} / \mathrm{C})$ rasio adalah perbandingan antara penerimaan dengan biaya produksi. Berdasarkan penerimaan dan biaya yang dikeluarkan, nilai penerimaan atas biaya $(\mathrm{R} / \mathrm{C})$ rasio atas biaya total yang diperoleh KTT Wiresinge adalah sebesar 1, 23. Berdasarkan penerimaan atas biaya (R/C) rasio sebesar 1,23 berarti untuk setiap $\mathrm{Rp}$. 1 biaya yang dikeluarkan, maka usaha KTT Wiresinge memberikan penerimaan sebesar Rp. 1, 23. Angka penerimaan atas biaya (R/C) rasio sebesar 1,23 menunjukkan bahwa usaha yang dijalankan oleh KTT Wiresinge di Desa Batukuta Kecamatan Narmada Kabupaten Lombok Barat menguntungkan.

Perhitungan hasil analisis penerimaan atas biaya $(\mathrm{R} / \mathrm{C})$ rasio dapat dilihat sebagai berikut:

$$
\begin{aligned}
\mathrm{R} / \mathrm{C} & =\frac{1.700 .000,-}{1.383 .000,-} \\
& =1.229
\end{aligned}
$$

Berdasarkan hasil analisis tersebut, jelas terbaca bahwa pengelolaan usaha pakan Amoniasi tersebut bagus untuk diusahakan dan dikembangkan, karena diperoleh nilai $\mathrm{R} / \mathrm{C}$ ratio lebih besar dari 1 (R/C Ratio >1) yaitu 1.23, yang berarti usaha pakan Amoniasi tersebut untung. Hasil analisis ini lebih rendah nilai R/C ratio nya dibandingkan dengan hasil penelitian (Wardoyo., 2016) yaitu nilai $\mathrm{R} / \mathrm{C}$ ratio nya sebesar 1.27 dan penelitian (Fitriyah, 2020) nilai R/C ratio nya sebesar 1.75 .

\section{Kesimpulan}

1. Biaya yang dikeluarkan dalam menjalankan usaha pakan Amoniasi KTT Wiresange di desa Batu Kuta Lombok Barat sebesar Rp.1.383.000,- 
2. Pendapatan dalam satu kali skala produksi (dua minggu) yang di peroleh KTT Wiresinge dari usaha pakan Amoniasi adalah sebesar Rp. 317.000,-

3. Secara ekonomis usaha pakan Amoniasi ini menguntungkan dan harus dikembangkan di desa Batu Kuta Lombok Barat, karena diperoleh nilai R/C Ratio sebesar 1.23 yang berarti bahwa setiap Rp. 1 biaya yang dikeluarkan akan memberikan penerimaan usaha sebesar Rp. 1,23.

\section{UCAPAN TERIMA KASIH}

Ucapan terima kasih kami sampaikan kepada Kementerian Pendidikan, Kebudayaan, Riset dan Teknologi, Badan Penelitian dan Pengembangan dan Perbukuan yang telah mendanai sepenuhnya kegiatan ini sesuai SP2H No. 091/SP2H/PPM/DRPM/2021, semua instansi maupun perseorangan yang telah memberikan dukungan moril dan materiil selama pelaksanaan kegiatan ini.

\section{DAFTAR PUSTAKA}

Fikriman, F. (2017). Tranformasi Pertanian dan Pembangunan Pedesaan. JAS (Jurnal Agri Sains), 1(2).

Fitriyah, A., Yuni Mariani, Isyaturriyadhah. (2020). Analisis Pendapatan Usaha Ternak Lebah Madu (Trigona Sp) Di Desa Sukadana Kecamatan Bayan Kabupaten Lombok Utara. Jurnal Agri Sains, 4(2), 162-167. Retrieved from https://ojs.umbbungo.ac.id/index.php/JAS/index

Husaini Usman, -., \& Purnomo Setiady Akbar, -. (2006). Pengantar statistika. Ed. 2. Retrieved from https://opac.perpusnas.go.id/Detail Opac.aspx?id=671483

Lilis Sulastri, D., MM. (2016, 1 (Februari, 2016)). Studi Kelayakan Bisnis Untuk Wirausaha. Retrieved from https://www.academia.edu/357573 85/STUDI_KELAYAKAN_BISNI S UNTUK WIRAUSAHA

Nazir, M., \& Sikmumbang, R. (2009). Metode penelitian. Retrieved from https://opac.perpusnas.go.id/Detail Opac.aspx?id=711887. Retrieved 18/7/2021, from Bogor : Ghalia Indonesia, 2009 https://opac.perpusnas.go.id/Detail Opac. $\operatorname{aspx}$ ?id=711887

Sapibagus. (2017). Cara Mengolah Amoniasi Jerami Untuk Pakan Sapi. Retrieved from https://www.sapibagus.com/caramengelola-amoniasi-jerami-untukpakan-sapi/. Retrieved 17 July 2021, from sapibagus Inspirasi dunia sapi Indonesia https://www.sapibagus.com/caramengelola-amoniasi-jerami-untukpakan-sapi/

Savinotes. (2017). Analisis Deskriptif. Retrieved from https://savinotes.wordpress.com/20 17/11/10/analisis-deskriptif-spss

Retrieved 18/07/2021, from QUANTITATIVE ANALYSIS, URP

https://savinotes.wordpress.com/20 17/11/10/analisis-deskriptif-spss

Statistik, B. P. (2020). Kecamatan Narmada Dalam Angka Narmada Subdistrict in Figures. Narmada, Lombok Barat, Nusa Tenggara Barat: CBPS Kabupaten Lombok Barat/Statistic of Lombok Barat Regency Retrieved from https://lombokbaratkab.bps.go.id

Suratiyah, K. (2015). Ilmu Usahatani (Edisi Revisi). Retrieved from https://www.bukularis.co.id/produc t/ilmu-usahatani-edisi-revisi/.

Retrieved 18/7/2021, from Penebar Swadaya https://www.bukularis.co.id/produc t/ilmu-usahatani-edisi-revisi/

Wardoyo, Moh. Romi., A. L., dan Afandi. (2016). Analisis Kelayakan Usaha 
Ternak Lebah Madu Jaya Makmur Di Desa Jono Oge Kecamatan Sigi Biromaru Kabupaten Sigi. e-J. Agrotekbis, 4(1), 84-90. Retrieved from

https://123dok.com/document/zx06 96oz-analisis-kelayakan-usahaternak-makmur-kecamatanbiromaru-kabupaten.html
Zhang, J., Yuan, J., Zhang, W. X., Tu, F., Jiang, Y., \& Sun, C. Z. (2018). Anaerobic detoxification fermentation by Rhodospirillum rubrum for rice straw as feed with moderate pretreatment. Prep Biochem Biotechnol, 48(1), 75-83. doi:10.1080/10826068.2017.14050 23 